\title{
Corn Products International (CPI) Financial analysis
}

\author{
Beili Zhang ${ }^{1, *}$ \\ ${ }^{1}$ China Petroleum Technology and Development Corporation, Beijing, 100028, China
}

\begin{abstract}
Corporation financial analysis is crucial for accounting research, including background and environment, revenue and profit, different kinds of financial ratios. This paper will analyze Corn Products International, a corn refining and ingredient companies.
\end{abstract}

\section{BACKGROUD}

Corn Products International (CPI) has existed under multiple names since 1906 . The company came into its current form in 1997 when its packaged food arm spun off to create Bestfoods Corporation and the remainder was incorporated as Corn Products International. Headquartered in the Chicago suburb of Westchester, Illinois, CPI is now one of the world's largest corn refining and ingredient companies.

It divides the business into three segments: North America, South America and Asia/Africa.

\section{PRODUCTS}

CPI's products mainly originate from the processing of corn and other starch-based materials. Their ingredients can be broken down into four major categories: starches, sweeteners, co-products, and others.

Starch products contribute to nearly $23 \%, 22 \%$ and $22 \%$ of the company's net sales for 2009, 2008 and 2007, respectively [ 1 ]. Due to starch's crucial usage in thickening and binding products, they are widely implemented into various fields. In the food industry, starches are used primarily to thicken or bind processed foods, frozen foods, and are also sold to food companies for direct sale to consumers.

Corn sweeteners are used in both foods and beverages. The sweeteners can be found in soft drinks, baked goods, confections, and dry food mixes.

Refined corn oil is sold to packers of cooking oil and producers of margarine, salad dressings, shortenings, mayonnaise and other foods.

[1] “Starch Products," CPI 2009 Annual Report, Page 9

${ }^{[2]}$ Graphs and summary data are used throughout this section for discussion purposes. See full ratio data in Exhibits 1-4, Source: Thomson ONE

\section{FINANCIAL RATIO ANALYSIS [2]}

This financial ratio analysis focus on the data of 20052009. The purpose is to use information from the financial statements to understand the health and standing of the company. This analysis will examine four groupings of ratios: Profitability, Asset Management, Liquidity, and Solvency.

The analysis will also compare CPI to its closest competitors. The companies involved are Archer-DanielsMidland, Tate \& Lyle, and Bunge Limited [3].

Exhibit 1: Corn Products International - 5 Year Ratio Comparison, Source: Thomson ONE

\begin{tabular}{|c|c|c|c|c|c|}
\hline $\begin{array}{c}\text { PROFITABILIT } \\
\text { Y RATIOS }\end{array}$ & 2005 & 2006 & 2007 & 2008 & 2009 \\
\hline Return On Assets & 4.87 & 5.79 & 8.00 & 9.36 & 2.03 \\
\hline $\begin{array}{c}\text { Gross Profit } \\
\text { Margin }\end{array}$ & 14.07 & 15.87 & 17.28 & 17.88 & 5.58 \\
\hline Net Margin & 3.81 & 4.73 & 5.84 & 6.77 & 1.12 \\
\hline Return on Equity & 7.86 & 9.76 & 13.49 & 17.87 & 2.68 \\
\hline $\begin{array}{c}\text { ASSET } \\
\text { MANAGEMENT } \\
\text { RATIOS }\end{array}$ & $\begin{array}{c}12 / 31 / \\
05\end{array}$ & $12 / 31 / 06$ & $12 / 31 / 07$ & $12 / 31 / 08$ & $12 / 31 / 09$ \\
\hline Asset Turnover & 0.99 & 0.98 & 1.09 & 1.23 & 1.25 \\
\hline $\begin{array}{l}\text { Inventory } \\
\text { Turnover }\end{array}$ & 7.45 & 7.22 & 7.17 & 7.06 & 7.87 \\
\hline $\begin{array}{c}\text { Accounts } \\
\text { Receivable Days }\end{array}$ & 44.70 & 44.84 & 43.97 & 50.30 & 51.74 \\
\hline $\begin{array}{c}\text { Inventories Days } \\
\text { Held } \\
\end{array}$ & 49.00 & 50.53 & 50.94 & 51.68 & 46.38 \\
\hline $\begin{array}{l}\text { LEVERAGE } \\
\text { RATIOS }\end{array}$ & $\begin{array}{c}12 / 31 / \\
05\end{array}$ & $12 / 31 / 06$ & 12/31/07 & $12 / 31 / 08$ & $12 / 31 / 09$ \\
\hline $\begin{array}{c}\text { Total Debt Pct } \\
\text { Common Equity }\end{array}$ & 63.45 & 54.13 & 47.73 & 48.17 & 44.13 \\
\hline $\begin{array}{l}\text { Total Debt Pct } \\
\text { Total Assets }\end{array}$ & 27.40 & 24.71 & 22.84 & 23.13 & 21.87 \\
\hline Dividend Payout & 28.16 & 24.61 & 20.62 & 17.85 & 21.81 \\
\hline $\begin{array}{l}\text { LIQUIDITY } \\
\text { RATIOS }\end{array}$ & $\begin{array}{c}12 / 31 / \\
05\end{array}$ & $12 / 31 / 06$ & $12 / 31 / 07$ & $12 / 31 / 08$ & $12 / 31 / 09$ \\
\hline Quick Ratio & 0.79 & 0.87 & 0.90 & 0.91 & 0.96 \\
\hline Current Ratio & 1.33 & 1.49 & 1.53 & 1.56 & 1.64 \\
\hline
\end{tabular}

[3] “Competition,” CPI 2009 Annual Report, Page 10

*Corresponding author: zhangbeili12@163.com 
Exhibit 2: Fiscal Year 2009 Ratio Comparison to Competitors

\begin{tabular}{|c|c|c|c|c|}
\hline Company & $\begin{array}{c}\text { Corn } \\
\text { Products } \\
\text { International } \\
\end{array}$ & $\mathrm{ADM}$ & $\begin{array}{l}\text { Tate \& } \\
\text { Lyle }\end{array}$ & $\begin{array}{l}\text { Bunge } \\
\text { Limited }\end{array}$ \\
\hline Quote Symbol & $\mathrm{CPO}$ & $\mathrm{ADM}$ & TATE & $\mathrm{BG}$ \\
\hline \multicolumn{5}{|l|}{$\begin{array}{c}\text { Profitability } \\
\text { Ratios }\end{array}$} \\
\hline $\begin{array}{c}\text { Return on } \\
\text { Equity }\end{array}$ & 2.68 & 13.67 & 1.65 & 4.09 \\
\hline $\begin{array}{l}\text { Return on } \\
\text { Assets }\end{array}$ & 2.03 & 6.98 & 1.97 & 2.75 \\
\hline $\begin{array}{c}\text { Gross Profit } \\
\text { Margin } \\
\end{array}$ & 5.58 & 5.53 & 31.69 & 3.93 \\
\hline $\begin{array}{l}\text { Net Profit } \\
\text { Margin }\end{array}$ & 1.12 & 3.13 & 0.43 & 0.86 \\
\hline \multicolumn{5}{|l|}{$\begin{array}{c}\text { Asset } \\
\text { Management } \\
\text { Ratios } \\
\end{array}$} \\
\hline Asset Turnover & 1.25 & 1.96 & 1.11 & 2.06 \\
\hline $\begin{array}{c}\text { Accounts } \\
\text { Receivable } \\
\text { Days } \\
\end{array}$ & 51.74 & 39.74 & 56.69 & 26.17 \\
\hline $\begin{array}{l}\text { Inventory } \\
\text { Turnover }\end{array}$ & 7.87 & 7.45 & 4.77 & 7.58 \\
\hline $\begin{array}{l}\text { Inventories } \\
\text { Days Held } \\
\end{array}$ & 46.38 & 48.97 & 76.51 & 48.17 \\
\hline \multicolumn{5}{|l|}{$\begin{array}{c}\text { Liquidity } \\
\text { Ratios }\end{array}$} \\
\hline Quick Ratio & 0.96 & 1.15 & 1.20 & 0.78 \\
\hline Current Ratio & 1.64 & 2.12 & 1.72 & 1.90 \\
\hline \multicolumn{5}{|l|}{$\begin{array}{c}\text { Solvency } \\
\text { Ratios }\end{array}$} \\
\hline $\begin{array}{c}\text { Debt to Equity } \\
(\%)\end{array}$ & 44.13 & 51.67 & 158.04 & 48.04 \\
\hline $\begin{array}{c}\text { Debt to Assets } \\
(\%)\end{array}$ & 21.87 & 23.93 & 41.56 & 18.79 \\
\hline $\begin{array}{c}\text { Dividend } \\
\text { Payout }\end{array}$ & 21.81 & 19.27 & $\# \mathrm{~N} / \mathrm{A}$ & 36.40 \\
\hline
\end{tabular}

\subsection{Profitability}

The first group of ratios examines the firm's returns relative to the assets and the equity invested in the firm. The first ratio examined is the return on assets. As seen in the chart below, CPI had an ROA that trended upward from $2005-2008$, starting at $4.87 \%$ in 2005 and reaching $9.36 \%$ in 2008 . The return on assets declines sharply in 2009 due to decreased revenues in the recessionary period. Exhibit 1 in Appendix shows the ROA and ROE from 2005-2009.

Even with the decline in 2009, the company shows a strong return on assets. The steady growth through 2008 is very healthy and while the sharp decline in 2009 is dramatic, it should not be cause for panic. The decline in revenue is more a reflection of the economic climate than the ability of CPI to generate revenue.

Examining ROE proves to tell the same story. The company had very strong growth from 2005-2008, peaking at 17.87. This means that for every dollar of equity, CPI earned \$.17. As seen in ROA, this ratio declines sharply in 2009 to 2.68 . While this is a dramatic change, this is more reflective of the economy as a whole rather than the health of the company.

The second group of ratios examines the margins of the company. The first ratio analyzed is gross profit margin. This ratio examines the percentage of revenue that flows into gross profit after subtracting out cost of goods sold. In 2005, CPI had a gross profit margin of $14 \%$ which grew steadily through 2008 , rising to $17.8 \%$ in
2008. There was a sharp decline in 2009 , taking the margin down to $5.58 \%$, a 12 percentage point swing that takes the gross profit margin well below the level it was in 2005. This is tied directly with the decrease in revenue in 2009. Exhibit 1 in Appendix shows the gross profit margin between $2005-2009$.

Again, the growth through the first four years examined is very healthy. While the sharp decline in 2009 is worrisome, it is no cause to reconsider the going concern of the company.

The next ratio is net profit margin, which compares net profit after taxes to revenue. The ratio trended upward from 2005 to 2008, reaching $6.77 \%$ in 2008. This growth is very steady and linear through the first four years. Again in 2009, we see a decline as we have in the ratios above, down to $1.12 \%$. Exhibit 1 in Appendix shows the net margin between 2005-2009.

This decline is very similar to gross margin above. Net margin dipped down below any of the previous margins. Gross profit margins can be very volatile and are more directly related to sales volume than operational effectiveness. Net profit margin considers operational effectiveness because it has factored in the other expenses that are more controllable by management strategy. This decline in net profit margin shows that while the company experienced a decline in revenue and a $12 \%$ drop in gross margin, the company controlled its expenses, cutting back to protect the bottom line. They held expenses below cost of sales to a little more than $4 \%$ of revenue, compared to $11 \%$ of revenue in 2008 . This illustrates a management that is adept at keeping profitable.

Comparing CPI's profitability ratios to its competitors will lead to a better understanding of the health of the firm. Below is a table with profitability ratios for CPI and its competitors from 2009 financial data.

Table 1: Profitability Ratios CPI \& Competitors, 2009. Source: Thomson ONE

\begin{tabular}{|lllll|}
\hline Company & $\begin{array}{l}\text { Corn Products } \\
\text { International }\end{array}$ & ADM & $\begin{array}{l}\text { Tate \& } \\
\text { Lyle }\end{array}$ & $\begin{array}{l}\text { Bunge } \\
\text { Limited }\end{array}$ \\
\hline $\begin{array}{l}\text { Return on } \\
\text { Equity }\end{array}$ & 2.68 & 13.67 & 1.65 & 4.09 \\
\hline $\begin{array}{l}\text { Return on } \\
\text { Assets }\end{array}$ & 2.03 & 6.98 & 1.97 & 2.75 \\
\hline $\begin{array}{l}\text { Gross Profit } \\
\text { Margin }\end{array}$ & 5.58 & 5.53 & 31.69 & 3.93 \\
\hline $\begin{array}{l}\text { Net Profit } \\
\text { Margin }\end{array}$ & 1.12 & 3.13 & 0.43 & 0.86 \\
\hline
\end{tabular}

For the gross profit margin, CPI is on equal footing with ADM, its much larger competitor, and has an advantage over Bunge Limited. Tate \& Lyle is a company that is much closer to CPI's size, but the company has a gross profit margin six times larger than CPI. This is more than likely related to Tate \& Lyle holding the rights to the production of Sucralose for Splenda. Since Splenda is a high price luxury good in the sweetener market, the high margin transfers back to the supplying company.

T\&L loses its advantage when looking at net profit margin. The company has the lowest at $0.43 \%$. CPI is the second highest at $1.12 \%$, only bested by ADM with their $3.13 \%$. ADM's margin is very healthy, which could be related back to how diversified the company is. CPI 
focuses primarily on corn, while ADM works with many agricultural products.

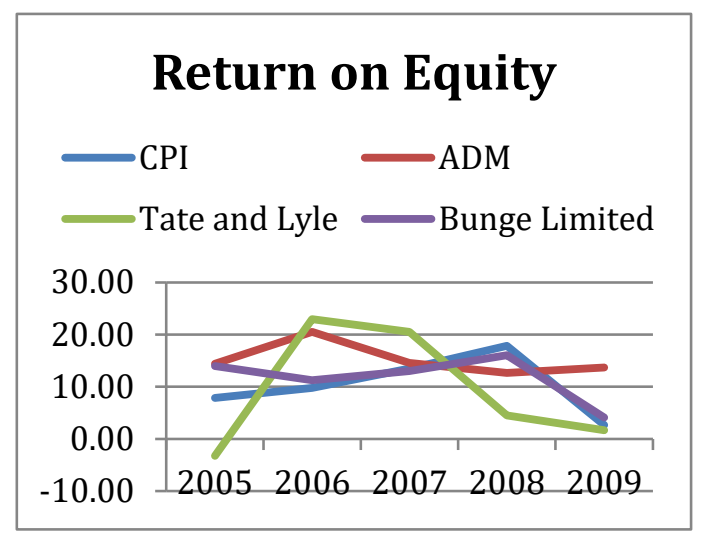

Figure 1: ROE Comparison 2005-2009 CPI \& Competitors Source: Thomson ONE

Above is a graph of each company's ROE for years 2005-2009. There is general growth for both CPI and Bunge Limited through 2008. ADM sees a slight increase in 2006, then a decline for the next two years. Tate \& Lyle swings from a $2005 \mathrm{ROE}$ of -3.24 to 22.95 in 2006 and sees a decline from then on. While CPI has the third lowest ROE in 2009, the company showed continual growth through 2008. ADM grew early on and then generally fell to 2009 and Tate \& Lyle went from negative to positive ROE then fell to the lowest amount in the group. Both Bunge and CPI have steady predictable ROE changes which speak to the predictability of both company's revenue streams.

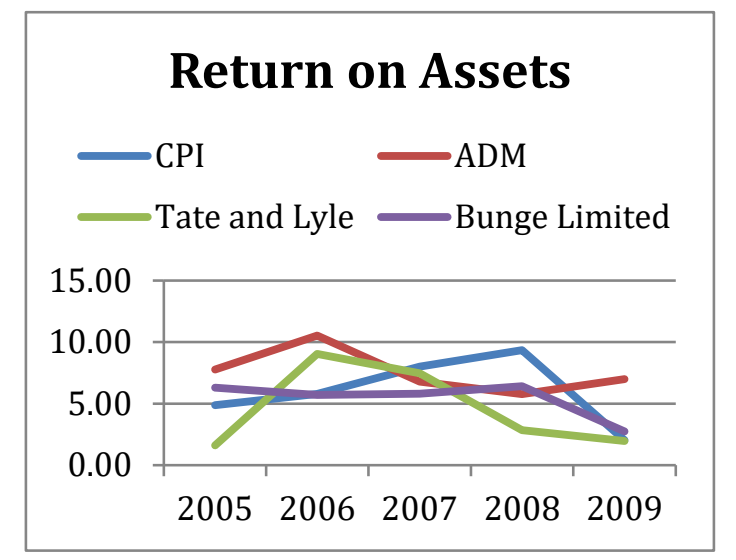

Figure 2: ROA Comparison CPI \& Competitors, 2005-2009 Source: Thomson ONE

Above is a graph of each company's ROA for years 2005-2009. ADM and Tate \& Lyle both had significant growth in 2006 then saw mostly decline to 2009. Bunge remained relatively steady through 2008 and then saw a sharp decline in 2009. CPI was the only company to have continual growth from 2005 to 2008 , but then the company had the sharpest decline into 2009. As in the individual analysis above, this decline is more representative of the economic climate rather than the health of CPI. With that, I would argue that CPI is positioned relatively well among its competitors with only ADM seeing an increase in 2009 due to its diversification.

\subsection{Asset Management Ratios}

The ratios below are indicators of how well company management is handling its assets. A company that does not have strong control of its assets will lose potential revenue through inefficiency. Below is a table detailing CPI's asset management ratios between 20052009(Exhibit1 in Appendix).

We will examine each ratio and its implications to the company. First is asset turnover; this ratio examines how many dollars in revenue are generated for every dollar in assets. This ratio shows great growth for CPI, starting at $\$ 0.99$ in 2005 and reaching $\$ 1.25$ in 2009 . This means that in 2009 , the company generated more revenue than the dollar amount it held in assets by $25 \%$.

Accounts receivable days measures how long the company takes to collect its receivables. CPI has shown negative growth in this ratio, starting at 44.7 days and ending at 51.74, a week longer to collect its receivables. This is an unhealthy trend, but can be explained by the weakening economy. Even so, the company needs to be aware of this ratio and keep a close watch on its change.

Inventory days held measures the average number of days the company took to sell its inventory. This number grew by two days from 2005-2008 and decreased to its lowest level in 2009 at 46 days. Again, this shows a healthy trend for the company, especially with the fiveday decrease form 2008 to 2009.

These asset management ratios look generally healthy for CPI but need to be compared to the other competitors to gauge how well the company is doing. Exhibit 2 in Appendix includes a table of asset management ratios for CPI and its competitors for 2009.

Asset turnover for CPI is lower than ADM and Bunge, which is more than likely related to the size of both of those companies. With a larger amount of revenue, fixed assets can be spread further, increasing this ratio. Compared to the similarly sized Tate \& Lyle, CPI is sitting in a slightly better position.

Accounts receivable days tells the same story, with ADM collecting 11 days faster and Bunge collecting 25 days faster. Bunge's speed can be explained with its contract with Splenda making up a large portion of its revenue, ensuring quick collectability. ADM is a larger company and holds more influence in the marketplace, more than likely garnering more respect by its customers. CPI collects 5 days faster than T\&L, but should strive for a quicker collection period.

Inventory days held appears to be healthy for CPI. The company leads again, this time by two days. ADM and Bunge are again close with Tate \& Lyle taking 30 more days.

\subsection{Liquidity}

Liquidity ratios measure the ability of companies to pay its debt over the short term. Exhibit1 in Appendix shows a chart of CPI's quick and current ratio.

The quick ratio divides current assets - inventory by current liabilities to create a ratio that provides an idea of how easily the company could pay its short term debt. The ratio shows continual growth from 2005 to 2009, ending 
with 0.96 . This means that the company could cover all but $4 \%$ of its current liabilities. This appears to be very healthy and does not show the company holding too much or too little cash.

The current ratio divides current assets by current liabilities. Considering that CPI's inventory days held averages around 50, this would be a measure that shows the ability of the company to pay its short-term debts over a three-month period. This ratio is very healthy from 2005 onward. While the quick ratio was not very healthy in the first couple years, this ratio includes inventory, which is a large part of the company's assets. The ratio continues to grow through 2009 and shows good management strategy. Exhibit 2 in Appendix shows a chart measuring the current and quick ratios for CPI and its competitors in 2009.

While CPI had shown growth to a generally strong quick ratio, ADM and Tate \& Lyle can both more than cover their short-term liabilities. Finding fault with this is difficult, both ratios are close enough to one to not signify too much cash on hand. Bunge shows an unhealthy number of 0.78 . They could not quickly cover their liabilities.

The current ratio proves to be similar with ADM and Tate \& Lyle, both ending with slightly better ratios than CPI. Bunge shows a significant increase in their ratio, signifying that a great deal of their current assets are inventory. While this is a much healthier number than their quick ratio, the company should not be comfortable with their short-term payment ability. CPI is relatively healthy in both of these measures and should have no cause for worry.

\subsection{Solvency}

Solvency ratios provide a look into how leveraged the company and how able the company is to pay its longterm debt. Exhibit1 in Appendix shows the three ratios for CPI using data from 2005-2009.

The debt to equity ratio measures how much debt the company holds compared to the money invested in it. The company shows a decline in the past five years of the percentage of debt to equity. In 2005, the company had a little more than one-third debt and two-thirds equity. In 2009, the company has less than one-third debt. The company is financed by two times more equity than debt. Both strategies, financed by debt or equity, are acceptable approaches, but the continual decreasing position of debt within the company shows that the company has a specific strategy to lower their debt.

The debt to assets ratio again shows a decline in the amount of debt the company holds. According to the ratio, in 2009 the company would have five-times the assets to its debts. This highlights the ability of the company to pay its long-term debts, easily covering these debts by five times. This is a low-risk strategy with the long-term reward of lesser interest expense.

Also included in this section is a dividend payout ratio which divides total dividends paid by net income. The ratio decreases from 2005 at $28 \%$ to 2009 at $22 \%$. This is a responsible move by the company considering the economic climate, but this also highlights the commitment to investors that the company has.

Exhibit 2 in Appendix includes a chart of measuring the solvency ratios of CPI and its competitors in 2009. The debt to equity ratio shows that $\mathrm{ADM}$ and Bunge have similar capital structures to CPI. All three companies are financed with one-third debt and two-thirds equity. Tate \& Lyle has the opposite strategy being two-thirds debt and one-third equity. I find it interesting that the two larger companies are similar to CPI while the similarly sized company uses the opposite strategy. This may speak to the ability of the three companies to issue equity or just may mean a different approach by T\&L.

The debt to assets ratio tells a similar story with ADM and Bunge hovering around one-fifth debt while T\&L is around two-fifths. The three similar companies, including CPI, are more solvent than T\&L. While the company can still cover their debts over two times with their assets, it still has less ability to pay these debts than its counterparts. The dividend payout ratio shows that CPI and ADM have similar dividend payout approaches hovering around 20\% of net income. Bunge paid out $36 \%$ of its net income, almost two times that of CPI and ADM. T\&L, on the other hand, did not pay out a dividend. Based on the solvency issues identified earlier, this is a good strategy for T\&L to reinvest in the firm.

\section{FORECASTS}

\subsection{Sales}

The first step in forecasting sales for CPI was to look at sales revenue for the past five and ten years. The table below shows calculation for the previous five years while the past ten years as well as accompanying calculations are in Exhibit 3 in the Appendix.

Exhibit 3: Change in Sales from 2000-2009

\begin{tabular}{|c|c|c|c|c|c|}
\hline & $12 / 31 / 00$ & $12 / 31 / 01$ & 12/31/02 & $12 / 31 / 03$ & $12 / 31 / 04$ \\
\hline Revenue & 1,865 & 1,887 & 1,871 & 2,102 & 2,283 \\
\hline \multirow[t]{2}{*}{ Growth } & & $1 \%$ & $-1 \%$ & $12 \%$ & $9 \%$ \\
\hline & $12 / 31 / 05$ & $12 / 31 / 06$ & $12 / 31 / 07$ & $12 / 31 / 08$ & $12 / 31 / 09$ \\
\hline Revenue & 2,360 & 2,621 & 3,391 & 3,944 & 3,672 \\
\hline \multirow[t]{5}{*}{ Growth } & $3 \%$ & $11 \%$ & $29 \%$ & $16 \%$ & $-7 \%$ \\
\hline & & Random & Walk & & $-7 \%$ \\
\hline & & 5- year & Mean & $\begin{array}{l}\text { Reversio } \\
\mathrm{n}\end{array}$ & $11 \%$ \\
\hline & & 10 -year & Mean & $\begin{array}{l}\text { Reversio } \\
\mathrm{n}\end{array}$ & $8 \%$ \\
\hline & & Mean & $\begin{array}{l}\text { Reversio } \\
\mathrm{n}\end{array}$ & w/o 2009 & $15 \%$ \\
\hline
\end{tabular}

Using the random walk method would generate a projected growth percentage of $-7 \%$. Using the mean reversion method for both the past five years and ten years generated a projected growth of $11 \%$ and $8 \%$, respectively. We also examined the unaudited data from first three quarters of 2010. The growth rate for these three quarters over the first three quarters of 2009 was $9 \%$ (see Exhibit 4 in Appendix for detail). 
Exhibit 4: Growth for First Three Quarters 2008-2010

\begin{tabular}{lccc} 
& 1st Qtr 2008 & 2nd Qtr 2008 & 3rd Qtr 2008 \\
\hline $\begin{array}{l}\text { Revenue } \\
\text { Growth }\end{array}$ & 991 & 1093 & 1155 \\
& & & \\
\hline Revenue & 1st Qtr 2009 & 2nd Qtr 2009 & 3rd Qtr 2009 \\
Growth & $\mathbf{8 8 1}$ & $\mathbf{9 6 6}$ & $\mathbf{1 0 2 7}$ \\
& $\mathbf{- 1 1 \%}$ & $\mathbf{- 1 2 \%}$ & $\mathbf{- 1 1 \%}$ \\
\hline Revenue & 1st Qtr 2010 & 2nd Qtr 2010 & 3rd Qtr 2010 \\
Growth & $\mathbf{9 9 5}$ & $\mathbf{1 0 6 6}$ & $\mathbf{1 0 8 3}$ \\
& $\mathbf{1 3 \%}$ & $\mathbf{1 0 \%}$ & $\mathbf{5 \%}$ \\
\cline { 2 - 4 } & & $\mathbf{2 0 0 9} \mathbf{3}$ Qs & $\mathbf{2 0 1 0 ~ 3 Q s}$ \\
\hline & & 2874 & 3144 \\
& Growth in 3Qs 2010 & & $9 \%$
\end{tabular}

Before deciding on a projected growth rate, another piece of data that is important to our decision is that CPI announced an acquisition in June 2010 of National Starch for $\$ 1.3$ billion (see Company Profile in Exhibit 5 in the Appendix). The acquisition is projected to be complete by the fourth quarter of 2010 , meaning that revenue from National Starch should be reflected in Q4 2010 and in the 2010 financial statements. Considering this as well as the possibility that the acquisition will not be complete by the end of 2010 , we chose a 2010 growth rate of $11 \%$.

Exhibit 5: National Starch Company Profile Source: AzkoNobel Report 2009

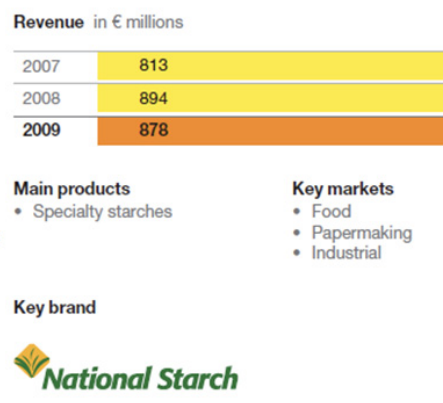

This figure is two percentage points greater than the actual rate for the first three quarters of 2010, but we feel that the likelihood of National Starch's revenue being included in the fourth quarter is high. Also, this growth rate is in line with the five-year historical rate. We feel the addition of National Starch will offset the ill effects of the continuing recessionary economic climate.

For 2011, National Starch will be fully included in the operations of CPI. Noting National Starch's 2009 revenue of $\$ 1.2$ billion, we predict that the acquisition will add $\$ 1$ billion in revenue to CPI for 2011. In order to project 2011 revenue, we first made the assumption that the company would grow consistently at $10 \%$. We came to this conclusion by looking at the five and ten-year mean reversion and choosing a number between the two figures. We feel that $10 \%$ is a sustainable baseline growth rate for the next five years.

With the $10 \%$ growth rate for 2011 , the company would have brought in $\$ 4.48$ billion. With the acquisition of National Starch and the assumption that this would generate approximately $\$ 1$ billion in revenue, we chose a

\footnotetext{
[4] Azko Nobel. Azko Nobel Report 2009 - National Starch. http://report.akzonobel.com/2009/businessperformance/akzono
}

growth rate of $34 \%$. This brings 2011 revenue to $\$ 5.46$ billion. After 2011 we continued to use a growth rate of $10 \%$ with the knowledge that after AzkoNobel acquired National Starch in 2008, the company reported National Starch's 2008 growth rate as $9.9 \%$ and 2009 as $-2 \%{ }^{[4]}$. With the company's history of innovative products, we feel that a growth rate of $10 \%$ is appropriate for the company. For 2012 through 2014, we used the 10\% growth rate. Below is a chart of projected growth from 2010-2014.

Table 2: Forecasted Sales Growth \& Revenues, 2010-2014

\begin{tabular}{|llllll|}
\hline & $\mathbf{2 0 1 0}$ & $\mathbf{2 0 1 1}$ & $\mathbf{2 0 1 2}$ & $\mathbf{2 0 1 3}$ & $\mathbf{2 0 1 4}$ \\
\hline Sales & 4,076 & 5,462 & 6,008 & 6,609 & 7,270 \\
\hline Growth \% & $11 \%$ & $34 \%$ & $10 \%$ & $10 \%$ & $10 \%$ \\
\hline
\end{tabular}

\subsection{Income Statement}

Continuing the forecast, we examined a five-year common sized income statement that can be found in Exhibit 6 . We calculated a mean for the five years for each line item and found that while some items stayed fairly even, many others varied unpredictably throughout the five years. Because of this we decided to use the mean averages for each line item in order to both accurately predict the line items that stayed fairly constant and also to hedge the risk of the varied line items by choosing a percentage that reflected overall change for the five years analyzed. As a result, we forecasted a common-sized income statement for the next five years which is Table 3 in the following.

Exhibit 6: Common-Sized Income Statement

\begin{tabular}{|c|c|c|c|c|c|c|}
\hline & $\mathbf{1 2 / 3 1 / 0 5}$ & $\mathbf{1 2 / 3 1 / 0 6}$ & $\mathbf{1 2 / 3 1 / 0 7}$ & $\mathbf{1 2 / 3 1 / 0 8}$ & $\mathbf{1 2 / 3 1 / 0 9}$ & Mean \\
\hline Revenues & $100.00 \%$ & $100.00 \%$ & $100.00 \%$ & $100.00 \%$ & $100.00 \%$ & $\mathbf{1 0 0 . 0 0 \%}$ \\
\hline COGS & $81.44 \%$ & $79.78 \%$ & $79.03 \%$ & $78.88 \%$ & $90.88 \%$ & $\mathbf{8 2 . 0 0 \%}$ \\
\hline $\begin{array}{c}\text { Depre.\& } \\
\text { Amort. }\end{array}$ & $4.49 \%$ & $4.35 \%$ & $3.69 \%$ & $3.25 \%$ & $3.54 \%$ & $\mathbf{3 . 8 6} \%$ \\
\hline $\begin{array}{c}\text { Gross } \\
\text { Income }\end{array}$ & $14.07 \%$ & $15.87 \%$ & $17.28 \%$ & $17.88 \%$ & $5.58 \%$ & $\mathbf{1 4 . 1 4 \%}$ \\
\hline $\begin{array}{c}\text { SG\&A } \\
\text { Exp. }\end{array}$ & $6.69 \%$ & $7.71 \%$ & $7.34 \%$ & $6.97 \%$ & $6.73 \%$ & $\mathbf{7 . 0 9 \%}$ \\
\hline $\begin{array}{c}\text { Operating } \\
\text { Income }\end{array}$ & $7.37 \%$ & $8.16 \%$ & $9.94 \%$ & $10.90 \%$ & $-1.14 \%$ & $\mathbf{7 . 0 5 \%}$ \\
\hline $\begin{array}{c}\text { Interest } \\
\text { Income }\end{array}$ & $0.21 \%$ & $0.23 \%$ & $0.35 \%$ & $0.13 \%$ & $0.03 \%$ & $\mathbf{0 . 1 9 \%}$ \\
\hline $\begin{array}{c}\text { Interest } \\
\text { Exp. On } \\
\text { Debt }\end{array}$ & $1.78 \%$ & $1.68 \%$ & $1.59 \%$ & $1.29 \%$ & $1.09 \%$ & $\mathbf{1 . 4 9 \%}$ \\
\hline $\begin{array}{c}\text { Pretax } \\
\text { Income }\end{array}$ & $6.23 \%$ & $7.48 \%$ & $8.99 \%$ & $10.27 \%$ & $3.13 \%$ & $\mathbf{7 . 2 2} \%$ \\
\hline $\begin{array}{c}\text { IncomeTa } \\
\text { xes }\end{array}$ & $2.33 \%$ & $2.63 \%$ & $3.01 \%$ & $3.30 \%$ & $1.85 \%$ & $\mathbf{2 . 6 2} \%$ \\
\hline $\begin{array}{c}\text { Minority } \\
\text { Interest }\end{array}$ & $0.13 \%$ & $0.15 \%$ & $0.15 \%$ & $0.20 \%$ & $0.16 \%$ & $\mathbf{0 . 1 6 \%}$ \\
\hline $\begin{array}{c}\text { Equity in } \\
\text { Earnings }\end{array}$ & $0.04 \%$ & $0.04 \%$ & $0.00 \%$ & $0.00 \%$ & $0.00 \%$ & $\mathbf{0 . 0 2} \%$ \\
\hline $\begin{array}{c}\text { Net } \\
\text { Income } \\
\text { Before } \\
\text { Preferred } \\
\text { Dividends }\end{array}$ & $3.81 \%$ & $4.73 \%$ & $5.84 \%$ & $6.77 \%$ & $1.12 \%$ & $\mathbf{4 . 4 5 \%}$ \\
\hline
\end{tabular}

Table 3: Forecasted Common-Sized Income Statement 20102014

\begin{tabular}{|cccccc|}
\hline & $12 / 31 / 10$ & $12 / 31 / 11$ & $12 / 31 / 12$ & $12 / 31 / 13$ & $12 / 31 / 14$ \\
& & & & & \\
\hline Revenues & $4,075.92$ & $5,461.73$ & $6,007.91$ & $6,608.70$ & $7,269.57$ \\
\hline
\end{tabular}

belspecialtychemicals/nationalstarch.html Accessed November $28,2010$. 


\begin{tabular}{|c|c|c|c|c|c|}
\hline COGS & $82.00 \%$ & $82.00 \%$ & $82.00 \%$ & $82.00 \%$ & $82.00 \%$ \\
\hline $\begin{array}{c}\text { Depre.\& } \\
\text { Amort. }\end{array}$ & $3.86 \%$ & $3.86 \%$ & $3.86 \%$ & $3.86 \%$ & $3.86 \%$ \\
\hline $\begin{array}{c}\text { Gross } \\
\text { Income } \\
\end{array}$ & $14.14 \%$ & $14.14 \%$ & $14.14 \%$ & $14.14 \%$ & $14.14 \%$ \\
\hline $\begin{array}{c}\text { SG \& A } \\
\text { Expenses }\end{array}$ & $7.09 \%$ & $7.09 \%$ & $7.09 \%$ & $7.09 \%$ & $7.09 \%$ \\
\hline $\begin{array}{c}\text { Operating } \\
\text { Income }\end{array}$ & $7.05 \%$ & $7.05 \%$ & $7.05 \%$ & $7.05 \%$ & $7.05 \%$ \\
\hline $\begin{array}{l}\text { Interest } \\
\text { Income }\end{array}$ & $0.19 \%$ & $0.19 \%$ & $0.19 \%$ & $0.19 \%$ & $0.19 \%$ \\
\hline $\begin{array}{c}\text { Interest } \\
\text { Exp. On } \\
\text { Debt } \\
\end{array}$ & $1.49 \%$ & $1.49 \%$ & $1.49 \%$ & $1.49 \%$ & $1.49 \%$ \\
\hline $\begin{array}{c}\text { Adjustme } \\
\text { nt Factor } \\
\text { for } \\
\text { Excluded } \\
\text { Data } \\
\end{array}$ & $1.47 \%$ & $1.47 \%$ & $1.47 \%$ & $1.47 \%$ & $1.47 \%$ \\
\hline $\begin{array}{c}\text { Pretax } \\
\text { Income } \\
\end{array}$ & $7.22 \%$ & $7.22 \%$ & $7.22 \%$ & $7.22 \%$ & $7.22 \%$ \\
\hline $\begin{array}{c}\text { IncomeTa } \\
\text { xes }\end{array}$ & $2.82 \%$ & $2.82 \%$ & $2.82 \%$ & $2.82 \%$ & $2.82 \%$ \\
\hline $\begin{array}{c}\text { Minority } \\
\text { Interest }\end{array}$ & $0.16 \%$ & $0.16 \%$ & $0.16 \%$ & $0.16 \%$ & $0.16 \%$ \\
\hline $\begin{array}{l}\text { Equity In } \\
\text { Earnings } \\
\end{array}$ & $0.00 \%$ & $0.00 \%$ & $0.00 \%$ & $0.00 \%$ & $0.00 \%$ \\
\hline $\begin{array}{c}\text { Net } \\
\text { Income } \\
\text { Before } \\
\text { Preferred } \\
\text { Dividends }\end{array}$ & $4.56 \%$ & $4.56 \%$ & $4.56 \%$ & $4.56 \%$ & $4.56 \%$ \\
\hline $\begin{array}{c}\text { Net } \\
\text { Income }\end{array}$ & 185.83 & 249.01 & 273.91 & 301.30 & 331.43 \\
\hline
\end{tabular}

\section{WORKING CAPITAL}

In order to forecast free cash flows to the firm, we first had to calculate change in working capital for the next five years. We calculated working capital first by pulling current assets from the balance sheet then subtracting cash and short-term investment. We then took this number and subtracted current liabilities to generate working capital. We calculated this for the previous five years which generated numbers between $\$ 145$ and $\$ 331$ million (Exhibit 7).

Exhibit 7: Operating Net Working Capital

\begin{tabular}{|c|c|c|c|c|c|}
\hline $\begin{array}{c}\text { Fiscal } \\
\text { Year } \\
\text { End }\end{array}$ & $\mathbf{1 2 / 3 1 / 0 9}$ & $\mathbf{1 2 / 3 1 / 0 8}$ & $\mathbf{1 2 / 3 1 / 0 7}$ & $\mathbf{1 2 / 3 1 / 0 6}$ & $\mathbf{1 2 / 3 1 / 0 5}$ \\
\hline $\begin{array}{c}\text { Current } \\
\text { Assets }\end{array}$ & $1,045.00$ & $1,297.00$ & $1,089.00$ & 837.00 & 685.00 \\
\hline $\begin{array}{c}\text { - Cash \& } \\
\text { ST } \\
\text { Investme } \\
\text { nts }\end{array}$ & 201.00 & 107.00 & 175.00 & 131.00 & 116.00 \\
\hline Total & 844.00 & $1,190.00$ & 914.00 & 706.00 & 569.00 \\
\hline $\begin{array}{c}\text { Current } \\
\text { Liabilities }\end{array}$ & 565.00 & 859.00 & 674.00 & 517.00 & 424.00 \\
\hline $\begin{array}{c}\text { Working } \\
\text { Capital }\end{array}$ & $\mathbf{2 7 9 . 0 0}$ & $\mathbf{3 3 1 . 0 0}$ & $\mathbf{2 4 0 . 0 0}$ & $\mathbf{1 8 9 . 0 0}$ & $\mathbf{1 4 5 . 0 0}$ \\
\hline $\begin{array}{c}\text { Working } \\
\text { Capital/ } \\
\text { Sales }\end{array}$ & $7.60 \%$ & $8.39 \%$ & $7.08 \%$ & $7.21 \%$ & $6.14 \%$ \\
\hline Average & $7.28 \%$ & & & & \\
\hline
\end{tabular}

In order to tie this data into the free cash flows calculation, we divided these figures by sales to create a working capital to sales ratio. The ratio ranged between $6.14 \%-8.39 \%$ with an average of $7.28 \%$. The ratio generally trended upward over the five years, so we felt that the company was working towards increasing their working capital. We decided to project an increase in working capital starting at $7.25 \%$ in 2010 then increasing in $.25 \%$ increments to $8 \%$ in 2013 and maintaining that level in 2014.

With the projected percentages we took our forecasted revenue numbers and multiplied them to generate a projected working capital dollar amount. We then calculated the year-to-year change in order to plug this into the FCFF calculation. These calculations can be seen in Table 4.

Table 4: Forecasted Net Working Capital

\begin{tabular}{|ccccccc|}
\hline $\begin{array}{c}\text { Fiscal } \\
\text { Year } \\
\text { End }\end{array}$ & $\mathbf{1 2 / 3 1 / 0 9}$ & $\mathbf{1 2 / 3 1 / 1 0}$ & $\mathbf{1 2 / 3 1 / 1 1}$ & $\mathbf{1 2 / 3 1 / 1 2}$ & $\mathbf{1 2 / 3 1 / 1 3}$ & $\mathbf{1 2}$ \\
\hline $\begin{array}{c}\text { Forecast } \\
\text { WC/Sale } \\
\text { s Ratio }\end{array}$ & & $7.25 \%$ & $7.50 \%$ & $7.75 \%$ & $8.00 \%$ & 8.0 \\
\hline $\begin{array}{c}\text { Working } \\
\text { Capital } \\
\text { Calculat } \\
\text { ed }\end{array}$ & 279 & 296 & 382 & 434 & 493 & 543 \\
\hline $\begin{array}{c}\text { Change } \\
\text { in } \\
\text { Working } \\
\text { Capital }\end{array}$ & & & & & & \\
\hline
\end{tabular}

\section{CAPITAL EXPENDITURES}

Another projection for FCFF is capital expenditures. In order to calculate this, we first looked at the previous five years. Over this time, capital expenditures ranged between $\$ 143$ million and \$228 million. These numbers steadily increased over the past five years due to investment by management in updating, expanding, and improving their facilities. Between 2008 and 2009 the number decreased due to cut backs in the bad economic climate. In 2009's 10-K, management predicted spending close to $\$ 200$ million in 2010 . This estimate comes before the knowledge of the National Starch acquisition. In order to project capital expenditures, we first needed to calculate them as a percentage of sales.

Over the past five years, capital expenditures to sales ratio have ranged between $3.98 \%$ and $6.52 \%$, with the average being $5.51 \%$. These calculations can be seen in Exhibit 8 . The ratio acted somewhat unpredictably, with it increasing and decreasing throughout the five years. For this reason, we decided to use the average capital expenditure ratio of $5.51 \%$ for all five projected years. For 2010, this generates estimated capital expenditures of \$225 million, which is \$25 million more than management predicted in last year's annual report, but takes into consideration potential increases in capital expenditures from the acquisition of National Starch. CPI has not issued a formal statement on how the company will approach operating National Starch, either investing heavily in growth or maintaining the business as it is. Because of this, we made the conservative estimate of a $\$ 25$ million overrun of the original plan. These calculations can be seen in Table 5 .

Exhibit 8: Capital Expenditure Analysis

\begin{tabular}{|c|c|c|c|c|c|}
\hline $\begin{array}{c}\text { Fiscal Year } \\
\text { End }\end{array}$ & $\mathbf{1 2 / 3 1 / 0 9}$ & $\mathbf{1 2 / 3 1 / 0 8}$ & $\mathbf{1 2 / 3 1 / 0 7}$ & $\mathbf{1 2 / 3 1 / 0 6}$ & $\mathbf{1 2 / 3 1 / 0 5}$ \\
\hline $\begin{array}{c}\text { Capital } \\
\text { Expenditures }\end{array}$ & 146.00 & 228.00 & 177.00 & 171.00 & 143.00 \\
\hline Sales & $3,672.00$ & $3,944.00$ & $3,391.00$ & $2,621.00$ & $2,360.00$ \\
\hline $\begin{array}{c}\text { Cap. } \\
\text { Ex./Sales }\end{array}$ & $3.98 \%$ & $5.78 \%$ & $5.22 \%$ & $6.52 \%$ & $6.06 \%$ \\
\hline
\end{tabular}




\begin{tabular}{|c|c|l|l|l|l|}
\hline $\begin{array}{c}\text { Avg. Cap. } \\
\text { Ex./Sales }\end{array}$ & $5.51 \%$ & & & & \\
\hline
\end{tabular}

Table 5: Forecasted Capital Expenditures

\begin{tabular}{|cccccc|}
\hline $\begin{array}{c}\text { Fiscal } \\
\text { Year End }\end{array}$ & $\mathbf{1 2 / 3 1 / 1 0}$ & $\mathbf{1 2 / 3 1 / 1 1}$ & $\mathbf{1 2 / 3 1 / 1 2}$ & $\mathbf{1 2 / 3 1 / 1 3}$ & $\mathbf{1 2 / 3 1 / 1 4}$ \\
\hline $\begin{array}{c}\text { Forecast } \\
\text { Cap. } \\
\text { Ex./Sales }\end{array}$ & 0.06 & 0.06 & 0.06 & 0.06 & 0.06 \\
\hline $\begin{array}{c}\text { Cap. Ex. } \\
\text { Calculated }\end{array}$ & 224.58 & 280.73 & 308.80 & 339.68 & 373.65 \\
\hline
\end{tabular}

\section{FREE CASH FLOWS}

As can be seen in Table 6, we calculated free cash flows to the firm over the next five years. We started with our projected sales figures and added back depreciation, depletion, and amortization costs. We then subtracted out working capital change that we calculated above to reach cash flow from operations. From that we subtracted out projected capital expenditures and added back after tax interest expense to reach our FCFF estimate.

Table 6: Forecasted Free Cash Flows to CPI, 2010-2014

\begin{tabular}{|lccccc|}
\hline $\begin{array}{l}\text { Fiscal } \\
\text { Year } \\
\text { Ending }\end{array}$ & $12 / 31 / 10$ & $12 / 31 / 11$ & $12 / 31 / 12$ & $12 / 31 / 13$ & $12 / 31 / 14$ \\
\hline $\begin{array}{l}\text { FCFF } \\
\text { Estimate }\end{array}$ & 139.00 & 141.98 & 199.22 & 217.75 & 254.93 \\
\hline
\end{tabular}

\section{FUTURE GROWTH RATE}

The future growth rate of the firm is necessary to calculate the terminal value in the DCF valuation method. In order to generate this number, we first looked at expected GDP growth. Standard \& Poor's is predicting growth of $2.8 \%$ in 2010 and $2.4 \%$ in 2011 after GDP shrunk by $2.6 \%$ in 2009 [5].

In our analysis, we projected a baseline growth rate of the firm at $10 \%$, with 2010 at $11 \%$ and 2011 at $34 \%$ because of the acquisition of National Starch. While in the short-term we feel this level of growth is achievable for CPI, the company will not be able to sustain this level forever. Because of this, we chose a future growth rate of $4.5 \%$. We feel this is a reasonable estimate because we predict that GDP will rise closer to the historical average of $3.5 \%$ in the coming years. Also, the company's acquisition of National Starch has the potential to lead to some high growth years because the company is focused on innovative technologies.

This long-term growth rate is less than half of the $10 \%$ growth we used for 2012-2014. Even so, we feel that a future growth rate of $4.5 \%$ is a reflection of our belief in CPI's ability to increase market share and grow the company. National Starch was a very smart acquisition as it will bring in a research side of the business that CPI had not had in the past.

\section{WEIGHTED AVERAGE COST OF CAPITAL}

In order to calculate the DCF for CPI, the weighted average cost of capital (WACC) must be computed. The WACC is then used to discount future cash flows to present value. It considers the cost of debt and cost of equity weighted against each other. Detailed calculations can be found in Exhibit 13 in the Appendix.

We applied the market value of equity to the WACC calculation. We computed the market value by multiplying shares outstanding at 2009 year-end $(74,386,000)$ by market value as of November 12,2010 (\$43.06). We chose to use current market value because it would better reflect the National Starch acquisition. This led to a market value of equity of approximately $\$ 3.2$ billion.

We calculated the cost of equity by using the Capital Asset Pricing Model (CAPM). This included a risk-free rate of $3.67 \%$ from the 10 -year composite Treasury Bill rate and a market return rate calculated by Prof. Gregory Jonas using historical market return data from the S\&P 500 . The market return used was $10.88 \%$. The beta used was 1.08 and was retrieved from Thomson One Banker. The calculation of cost of equity yielded $11.31 \%$.

The book value of debt was used in the WACC calculation. This number was calculated by taking the weighted average interest rate of long-term notes. The data was found in Note 6 - Financing Arrangements in CPI's 2009 10-K. The company had two senior notes with an average interest rate of $6.15 \%$. After considering the effective tax rate of $35 \%$, CPI's cost of debt equals $4 \%$.

The capital structure of the firm is $14.52 \%$ debt and $85.48 \%$ equity. With all of the above factors included, the WACC is calculated as $10.25 \%$.

Equity:

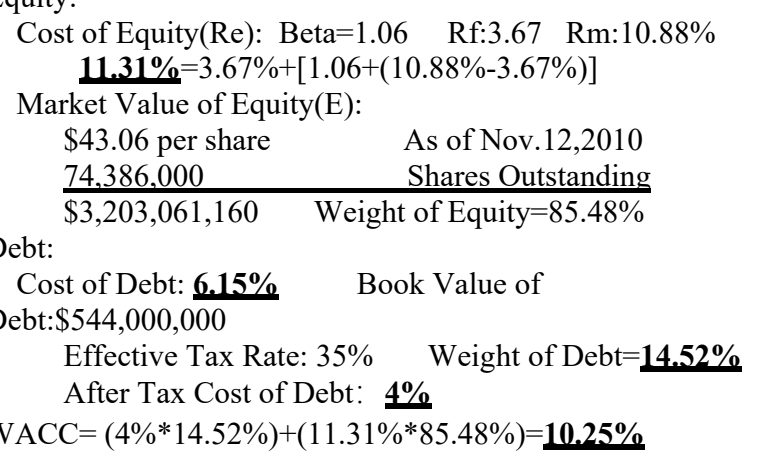

\section{TERMINAL VALUE}

Once the WACC was calculated, we were able to calculate the terminal value of the company. The calculations can be found in Table 7. Using the growth rate of $4.5 \%$ chosen above, the calculated cash flow in perpetuity was $\$ 266.4$ million. Using the WACC of $10.25 \%$, the terminal value of the company is estimated at $\$ 4,633.12$ million.

$$
\mathrm{g}=4.5 \% \quad \text { WACC }=10.25 \% \quad \text { FCFF } 2014=\$ 254.93
$$

[5] Standard \& Poor's. The Outlook: Intelligence for the Individual Investor. Edition Dec. 1, 2010. Volume 82. 
Terminal Value as of $2014 \quad[\$ 254.93 *(1+4.5 \%)] /(10.25 \%$ $4.5 \%)=\$ 4,633.12$

Table 7: Forecasted Free Cash Flows to the Firm, 2010-2014

\begin{tabular}{|c|c|c|c|c|c|}
\hline $\begin{array}{l}\text { Fiscal Year } \\
\text { End }\end{array}$ & $12 / 31 / 10$ & $12 / 31 / 11$ & $12 / 31 / 12$ & $12 / 31 / 13$ & $12 / 31 / 14$ \\
\hline Net Income & 185.83 & 249.01 & 273.91 & 301.30 & 331.43 \\
\hline $\begin{array}{c}+ \\
\text { Depreciation, } \\
\text { Depletion, } \\
\text { and } \\
\text { Amortization }\end{array}$ & 157.33 & 210.82 & 231.91 & 255.10 & 280.61 \\
\hline WC Change & 17 & 87 & 52 & 59 & 49 \\
\hline $\begin{array}{l}\text { Cash Flow } \\
\text { from } \\
\text { Operations }\end{array}$ & 326.65 & 373.22 & 453.59 & 497.55 & 562.72 \\
\hline $\begin{array}{c}\text { - Cash Flow } \\
\text { from } \\
\text { Investing }\end{array}$ & 225 & 281 & 309 & 340 & 374 \\
\hline $\begin{array}{c}\text { After Tax } \\
\text { Interest } \\
\text { Expense }\end{array}$ & 36.93 & 49.49 & 54.43 & 59.88 & 65.86 \\
\hline $\begin{array}{c}\text { FCFF } \\
\text { Estimate }\end{array}$ & 139.00 & 141.98 & 199.22 & 217.75 & 254.93 \\
\hline
\end{tabular}

\section{CONCLUSION}

Considering the four categories of financial ratios, CPI seems to be in generally good health. The company's profitability ratios are sound, with the only blemish coming from last year's negative revenue growth. The company has good asset management, only needing to look into lowering its accounts receivable day's ratio to be more comparable to ADM. The liquidity and solvency ratios indicate a strong ability to pay short and long-term debts. Overall, the company is in good health and the terminal value of the company is estimated at $\$ 4,633.12$ million.

\section{References}

1. “Starch Products," CPI 2009 Annual Report, Page 9.

2. Source: Thomson ONE

3. "Competition," CPI 2009 Annual Report, Page 10

4. Azko Nobel. Azko Nobel Report 2009 - National Starch.

http://report.akzonobel.com/2009/businessperforma nce/akzonobelspecialtychemicals/nationalstarch.htm 1 Accessed November 28, 2010.

5. Standard \& Poor's. The Outlook: Intelligence for the Individual Investor. Edition Dec. 1, 2010. Volume 82. 